\title{
APPLICATION OF TECHNOLOGY AUGMENTED REALITY IN BROCHURES SMK GHAMA CARAKA DEPOK BASED ANDROID
}

\author{
Indarti; Dewi Laraswati \\ ${ }^{1}$ Information System; ${ }^{2}$ Computer Technology \\ Faculty of Information Technology, Bina Sarana Informatics University \\ www.bsi.ac.id \\ indarti.ini@bsi.ac.id; dewi.dwl@bsi.ac.id
}

\begin{abstract}
Abstrak
Brosur adalah salah satu instrumen penting dalam hal promosi dengan tujuan untuk memberikan informasi awal bagi calon siswa, tetapi brosur yang saat ini digunakan masih terbilang klasik. Masih menggunakan selebaran brosur dengan media kertas dan informasi yang disampaikan tergantung pada ukuran dari besarnya brosur yang dicetak. Jika pihiak sekolah ingin memberikan informasi lebih banyak dengan menambahkan banyak gambar dengan dilengkapi detail produk, maka semakin besar ukuran brosur yang harus dicetak. Penelitian yang dilakukan menggunakan konsep augmented reality dalam pembuatan brosur interaktif berbasis android. Adapun tahapan yang dilakukan terdiri dari analisis kebutuhan perangkat lunak dan perangkat keras yang akan digunakan. Metode penelitian menggunakan metode studi kasus, dengan pendekatan kualitatif. Sedangkan untuk model pengembangan aplikasi ini menggunakan model waterfall yang merupakan metode dalam SDLC, urutan langkah-langkah yang digunakan dalam penelitian ini adalah analisis kebutuhan sistem, desain, pembuatan kode program, pengujian dan pendukung.
\end{abstract}

Kata kunci: Augmented Reality, Brosur, Android

\begin{abstract}
The brochure is one of the important instruments in terms of promotion to provide initial information for prospective students, but the brochure currently used is still fairly classic. Still using brochure leaflets on paper media and the information conveyed depends on the size of the printed brochure. If the school committee wants to provide more information by adding lots of pictures with product details, the larger the size of the brochure that needs to be printed. Research conducted using the concept of augmented reality in making interactive brochures based on Android. The steps involved consist of analyzing the software and hardware requirements to be used. The research method uses the case study method, with a qualitative approach. As for the application development model using the waterfall model which is a method in SDLC, the sequence of steps used in this research is system requirement analysis, design, program code making, testing and support.
\end{abstract}

Keywords: Augmented Reality, Brochures, Android

\section{INTRODUCTION}

The development of augmented reality in Asia is increasing released at https:// pressrelease.kontan.co.id on 21 January 2020 (Daniel Rembeth, 2020) that augmented reality will increase the global economy to 1,4 trillion pounds in 2030.

In the product promotion augmented reality can be applied is where a brand will do promotional activities by interacting nearer to the user. through various activities Promotional purposes are introduced for the general public in a brand owned in the hope of buyers and consumers could be interested in products offered intertwining and a good relationship with consumers.

The use of augmented reality in the form of interactive brochures made in brochures is implemented in the form of interactive brochures which can contain information about complaints submitted in the form of brochures that are presented in 3D and supported virtually through smartphones.

The source of literature used in this study is related to theory and material so that the research made has a solid and scientific basis. Some previous research sources that can be adopted by the authors, as below. 
Augmented Reality is the output generated from computer processes that display objects in cyberspace and the real world. The virtual display can be presented in various forms such as video animation text, and 3D models that are presented on real objects in the environment where we will display virtual objects.

Promotions are carried out conventionally one of which is to use brochures (Yuliati et al., 2014). In the brochure usually contains several pages that will provide information about the products offered so that consumers are interested

Vuforia in research (Mustaqim \& Kurniawan, 2017) is software that focuses on image recognition to support augmented reality technology.

According to (Rizal \& Rusmin, 2018) explains that Unity $3 \mathrm{D}$ is a game engine that allows you, both individuals and teams, to create a 3D game easily and quickly

According to (Adami \& Budihartanti, 2016) explained that: "C \# (read" C-Sharp ") is an objectoriented programming language, created by Microsoft (developed under the leadership of Anders Hejlsberg who also invented various programming languages).

Research on augmented reality is currently widely discussed and utilized in various fields ranging from the use of technology in the fields of education, health, and media promotion tools. Below are some of the previous studies on the use of augmented reality technology and researchers using materials to get the theory used to obtain materials used to make materials from research that is made. Below can be seen as an explanation of the initial studies, namely:

Table 1. Literature Research

\begin{tabular}{|c|c|c|c|}
\hline Author & Research Problem & Method & Research Results \\
\hline $\begin{array}{l}\text { Tri Yuliati, Ema } \\
\text { Utami, Hanif Al Fatta } \\
\text { (Yuliati et al., 2014) }\end{array}$ & $\begin{array}{l}\text { Promotional media is still } \\
\text { conventional (Yuliati et al., 2014) }\end{array}$ & $\begin{array}{l}\text { IMSDD mobile Augmented } \\
\text { Reality (Yuliati et al., 2014) }\end{array}$ & $\begin{array}{l}\text { Mobile applications using the Android } \\
\text { platform with Augmented Reality } \\
\text { technology are expected to be able to } \\
\text { display brochures that are presented } \\
\text { in an interesting and real-time } \\
\text { manner. (Yuliati et al., 2014) }\end{array}$ \\
\hline $\begin{array}{l}\text { Dedy Abdullah, } \\
\text { Alkausar Sani, Amir } \\
\text { Hasan (Abdullah et } \\
\text { al., 2019) }\end{array}$ & $\begin{array}{l}\text { Lack of information and } \\
\text { promotional media that is not } \\
\text { interesting and not interactive } \\
\text { causes the number of visitors to } \\
\text { this location to be very low. } \\
\text { (Abdullah et al., 2019) }\end{array}$ & $\begin{array}{l}\text { Incremental Method } \\
\text { (Abdullah et al., 2019) }\end{array}$ & $\begin{array}{l}\text { The results showed the augmented } \\
\text { reality application system of Bung } \\
\text { Karno's residence could run well. } \\
\text { (Abdullah et al., 2019) }\end{array}$ \\
\hline $\begin{array}{l}\text { Ilmawan Mustaqim } \\
\text { and Nanang } \\
\text { Kurniawan } \\
\text { (Mustaqim \& } \\
\text { Kurniawan, 2017) }\end{array}$ & $\begin{array}{l}\text { Teachers will be more difficult to } \\
\text { explain to students about the } \\
\text { various types of pneumatic } \\
\text { components and their use. } \\
\text { (Mustaqim \& Kurniawan, 2017) }\end{array}$ & $\begin{array}{l}\text { Experimental research } \\
\text { methods (Mustaqim \& } \\
\text { Kurniawan, 2017) }\end{array}$ & $\begin{array}{l}\text { The results of research in the form of } \\
\text { development of instructional media } \\
\text { using augmented reality are useful as } \\
\text { teaching materials in virtual form. } \\
\text { (Mustaqim \& Kurniawan, 2017) }\end{array}$ \\
\hline $\begin{array}{l}\text { Muhammad Rizal } \\
\text { and Muhammad } \\
\text { Rusmin (Rizal \& } \\
\text { Rusmin, 2018) }\end{array}$ & $\begin{array}{l}\text { In promoting property there are } \\
\text { still many companies using } \\
\text { marketing media in the form of } \\
\text { brochures and websites. At } \\
\text { present, the media is considered } \\
\text { less effective and less attractive } \\
\text { with limitations in displaying the } \\
\text { marketed property models. } \\
\text { (Rizal \& Rusmin, 2018) }\end{array}$ & $\begin{array}{l}\text { SDLC agile method (Rizal \& } \\
\text { Rusmin, 2018) }\end{array}$ & $\begin{array}{l}\text { Generating an application that runs on } \\
\text { the Android platform as one of the } \\
\text { activities undertaken to market } \\
\text { products offered with attractive and } \\
\text { effective media using only the } \\
\text { smartphone that has the information } \\
\text { received represents what is being } \\
\text { sold. (Rizal \& Rusmin, 2018) }\end{array}$ \\
\hline $\begin{array}{l}\text { Sari Indah Anatta } \\
\text { Setiawan (Setiawan, } \\
\text { 2011) }\end{array}$ & $\begin{array}{l}\text { There are still many people who } \\
\text { do not know about the functions } \\
\text { and benefits of Google SketchUp } \\
\text { in the use of 3D modeling } \\
\text { software (Setiawan, 2011) }\end{array}$ & $\begin{array}{l}\text { Experiment Method } \\
\text { (Setiawan, 2011) }\end{array}$ & $\begin{array}{l}\text { This research aims to introduce } \\
\text { Google SketchUp to the people of } \\
\text { Indonesia, especially academics so } \\
\text { that they can utilize this software as } \\
\text { an alternative tool in 3D modeling. } \\
\text { (Setiawan, 2011) }\end{array}$ \\
\hline $\begin{array}{l}\text { Feby Zulham Adami } \\
\text { and Cahyani } \\
\text { Budihartanti (Adami } \\
\text { \& Budihartanti, } \\
\text { 2016) }\end{array}$ & $\begin{array}{l}\text { How to apply augmented reality } \\
\text { technology on android-based } \\
\text { learning media. (Adami \& } \\
\text { Budihartanti, 2016) }\end{array}$ & $\begin{array}{l}\text { Data collection methods used } \\
\text { are observation methods, } \\
\text { interview methods, and } \\
\text { literature study methods. } \\
\text { The software system } \\
\text { development methodology } \\
\text { that researchers use is the } \\
\text { Waterfall model. (Adami \& } \\
\text { Budihartanti, 2016) }\end{array}$ & $\begin{array}{l}\text { Producing a learning application using } \\
\text { augmented reality technology using a } \\
\text { smartphone. (Adami \& Budihartanti, } \\
\text { 2016) }\end{array}$ \\
\hline $\begin{array}{l}\text { Indarti (Indarti, } \\
\text { 2017) }\end{array}$ & $\begin{array}{l}\text { The learning process at Pondok } \\
\text { Pinang } 10 \text { Morning Elementary } \\
\text { School with the process of } \\
\text { students listening to explanations }\end{array}$ & $\begin{array}{l}\text { Literature Study Methods. } \\
\text { (Indarti, 2017) }\end{array}$ & $\begin{array}{l}\text { Generating an application that } \\
\text { contains an introduction of national } \\
\text { heroes on the island of Java which is } \\
\text { intended for students based on }\end{array}$ \\
\hline
\end{tabular}




\begin{tabular}{|c|c|c|c|}
\hline Author & Research Problem & Method & Research Results \\
\hline & $\begin{array}{l}\text { from the teacher and seeing and } \\
\text { reading books that might lead to } \\
\text { boredom in students. (Indarti, } \\
\text { 2017). }\end{array}$ & & $\begin{array}{l}\text { Pondok Pinang } 10 \text { Pagi Elementary } \\
\text { School based on android. (Indarti, } \\
\text { 2017) }\end{array}$ \\
\hline $\begin{array}{l}\text { Bonny A } \\
\text { Suryawinata } \\
\text { (Suryawinata, 2010) }\end{array}$ & $\begin{array}{l}\text { Existing home marketing media is } \\
\text { still conventional (Suryawinata, } \\
\text { 2010) and 2D in a form so it is } \\
\text { less attractive to buyers and } \\
\text { difficult to imagine the condition } \\
\text { of the house. }\end{array}$ & $\begin{array}{l}\text { Literature Study Methods. } \\
\text { (Suryawinata, 2010) }\end{array}$ & $\begin{array}{l}\text { Design an application that can display } \\
\text { 3D images via the internet by utilizing } \\
\text { augmented reality technology } \\
\text { (Suryawinata, 2010), so that potential } \\
\text { homebuyers can access this } \\
\text { application anytime and anywhere. }\end{array}$ \\
\hline
\end{tabular}

The purpose of the research carried out by researchers to develop software in the distribution of school brochures is to be able to help visitors find the location of the school or class by utilizing augmented reality technology based on android.

\section{RESEARCH METHODS}

In this study, the authors used the case study method. By investigating Caraka Depok Vocational High School, particularly in the area of school promotion, a problem was discovered. This research was conducted by researchers using a waterfall model. This model provides a sequential or sequential software life cycle approach, which is:

1. Communication (Initiation Meeting and Requirements)

Communication in studies is technical work and is needed by users to achieve goals with the results of project initialization that analyzes problems in AR research to facilitate the process of introducing schools or company profiles and is useful for users in knowing school facilities and infrastructure created by researchers.

2. Planning (Estimating, Scheduling, Tracking) The planning stage of the researcher is to make software features by describing facilities and infrastructure in the school, the risks that will arise when creating Augmented Reality School Brochures, the resources needed by researchers to create brochures using Augmented Reality, the products to be produced under analysis and drafts that are made and work schedule for making this Augmented Reality brochure.

3. Modeling (Analysis \& Design)

The model that will be used at this stage is adjusted to the design that has been made by researchers and adjusted to the final appearance of the brochure with Augmented Reality. In the model stage consists of 2 namely analysis and design, each of which has a picture, namely:

a. Analysis
Having specifications of user requirements, among others:

1) The scope of information describes a data processing, both the data displayed, and the features that will be displayed in the brochure.

2) Functional Scope describes the functions of the features that will be displayed to the Augmented Reality Brochure users.

3) The Scope of behavior describes the events caused by features that have been created using the Augmented Reality brochure.

b. Design

Various specifications are arranged in the making of this Augmented Reality brochure, which starts from the software structure, components, and appearance of the Augmented Reality brochure to the user.

4. Construction (Code \& Test)

This construction phase adds the creation of program code and application testing of Augmented Reality applications that have been made by researchers utilizing unit testing, integration testing, validation testing, and acceptance testing.

5. Deployment (Delivery, Support, Feedback)

Submission of the system found by the makers of three (3) components, namely, sending messages in the making of this Augmented Reality brochure, providing facilities in using the Augmented Reality brochure and feedback to users in using this Augmented Reality brochure more easily and efficiently without opening directly to the school to inspect facilities and infrastructure in the school.

\section{Types of research}

This research uses a qualitative approach. The approach taken by the author is by making observations (direct observation) at SMK Ghama Caraka Depok and conducting interviews especially in the field of a school promotion.

\section{Time and Place of Research}

SMK Ghama Caraka was established on December 12, 2018, under the Ghama Educational Institution's d'Leader School. The school, which is 
located at Jalan Raya Grogol No. 3, Grogol Village, Limo District, Depok City, has only one department or one package of expertise, namely in the field of Broadcasting, with Television Program Broadcasting Production Expertise Competency (PSPT).

\section{Research Targets / Subjects}

At the beginning of the founding of SMK Ghama Caraka, namely the 2013-2014 Academic Year to date, the registered students are listed as follows:

Table 2. Student Recapitulation on SMK GHAMA Caraka Depok

\begin{tabular}{cccccc}
\multicolumn{4}{c}{ Caraka Depok } \\
\cline { 2 - 4 } SCHOOL YEAR & \multicolumn{3}{c}{ SMK GHAMA CARAKA } & \multirow{2}{*}{ TOTAL } \\
\cline { 2 - 4 } & \multicolumn{3}{c}{ INNOVATION } & \\
\cline { 2 - 4 } & L & P & JLH & 69 \\
$2013 / 2014$ & 26 & 43 & 69 & 70 \\
$2014 / 2015$ & 34 & 36 & 70 & 46 \\
$2015 / 2016$ & 18 & 28 & 46 & 50 \\
$2016 / 2017$ & 27 & 23 & 50 & 63 \\
$2017 / 2018$ & 50 & 13 & 63 & 56 \\
$2018 / 2019$ & 36 & 20 & 56 &
\end{tabular}

Source : (Yayasan Pendidikan GHAMA d'leader school, 2018)

Over time, competition between schools with television broadcasting majors has experienced a very significant surge with the establishment of competitor schools, there are even some courses that open broadcast competency packages in the City of Depok. This is a challenge for SMK Ghama Caraka to continue to show its existence, with a variety of strategies that have been carried out by this school, but with the student admission data above, schools must provide different experiences to each prospective applicant to become a brand image of the broadcasting school.

\section{RESEARCH RESULTS AND DISCUSSION}

The results in this study are based on the waterfall model used by the author in developing a software application as follows:

\section{A. Communication}

Analysis of the system requirements of researchers using the Android platform based on interviews with the marketing team Most applicants and employees use the Android platform. Analysis of system requirements used in the development of this system:

1. Users can scan brochures

2. Users can display the virtual object above

3. Users can register new students

\section{B. Planning}

At this stage table 3 can be seen planning software development activities, as follows:

Table 3. Activity Plan

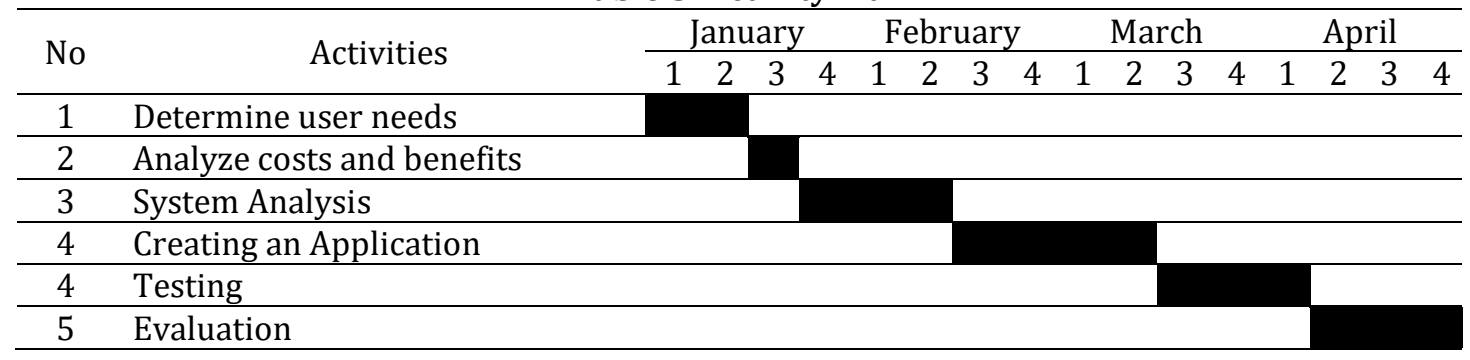

\section{Modelling}

The design carried out by researchers is to create virtual object modeling designs such as school buildings, then create database designs where this process is created using Vuforia, the contents of the database are target markers or images that will be recognized by the application. Besides making software architecture, where researchers use State Transition Diagrams (STD), Use Case Diagrams, and Structure Navigation.

\section{Use Case Diagram}

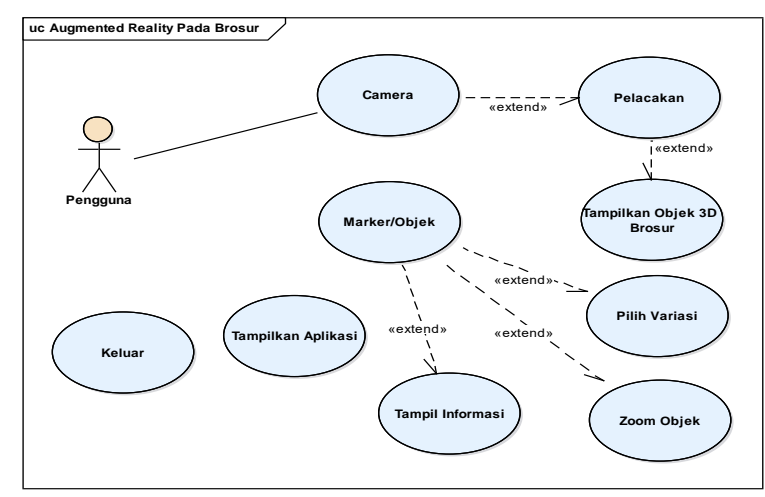

Figure 1 Use Case Augmented Reality Diagrams on the Brochure 
The use case diagram in the picture above can be explained in the Scenario table for the "User" use case as follows:

Table 4. User Use Case Scenarios

\begin{tabular}{lll}
\hline $\begin{array}{l}\text { Use Case } \\
\text { Name }\end{array}$ & $: \begin{array}{l}\text { Use Case Augmented Reality Diagrams } \\
\text { on the Brochure }\end{array}$ \\
\hline $\begin{array}{l}\text { Use Case } \\
\text { Description }\end{array}$ & $: \begin{array}{l}\text { Users can apply the camera to the } \\
\text { brochure }\end{array}$ \\
\hline Actors & $:$ & User \\
\hline $\begin{array}{l}\text { Pre- } \\
\text { Condition }\end{array}$ & $:$ & AR application on Android phone \\
\hline $\begin{array}{l}\text { Post- } \\
\text { Condition }\end{array}$ & $:$ & $\begin{array}{l}\text { Activate the Camera and scan the } \\
\text { Marker on the Brochure }\end{array}$ \\
\hline $\begin{array}{l}\text { Main } \\
\text { Scenarios }\end{array}$ & $:$ & Serial Step \\
\hline
\end{tabular}

\begin{tabular}{lcl}
\hline & No. & \\
\hline Actor & 1 & AR Camera \\
\hline & 2 & Marker / Object \\
\hline & 3 & Showing Application \\
\hline & 4 & Exit \\
\hline
\end{tabular}

\begin{tabular}{lll}
\hline & \multicolumn{2}{c}{ Access } \\
\hline Extensions & 1a & Tracking \\
\hline & 1b & Show 3D Brochure Objects \\
\hline 2a & Select variations \\
\hline 2c & Object Zoom \\
\hline 2d & Information displayed \\
\hline
\end{tabular}

2. Activity Diagram

a. Activity diagram Activity Diagram Display 3D Object Brochure

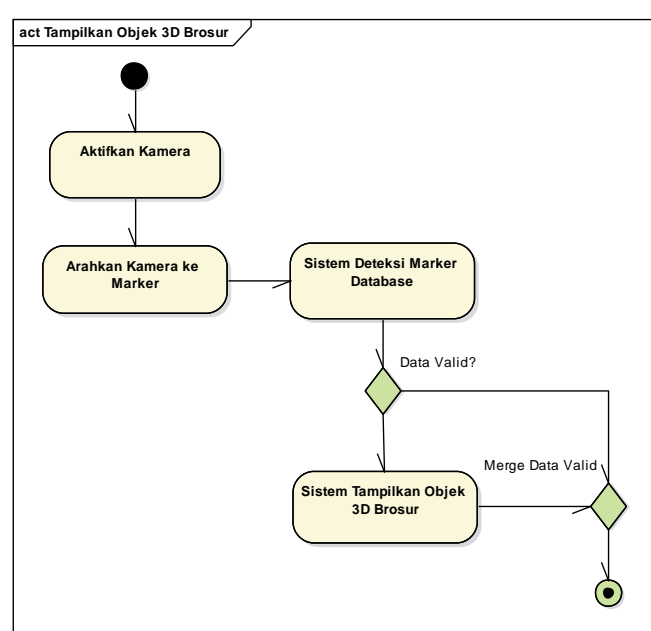

Figure 2 Activity Diagram Show 3D Objects Brochure

Figure 2 above illustrates the activity diagram of the user (user) for displaying 3D brochures with augmented reality technology. a. Activity diagram of the Object Zoom process

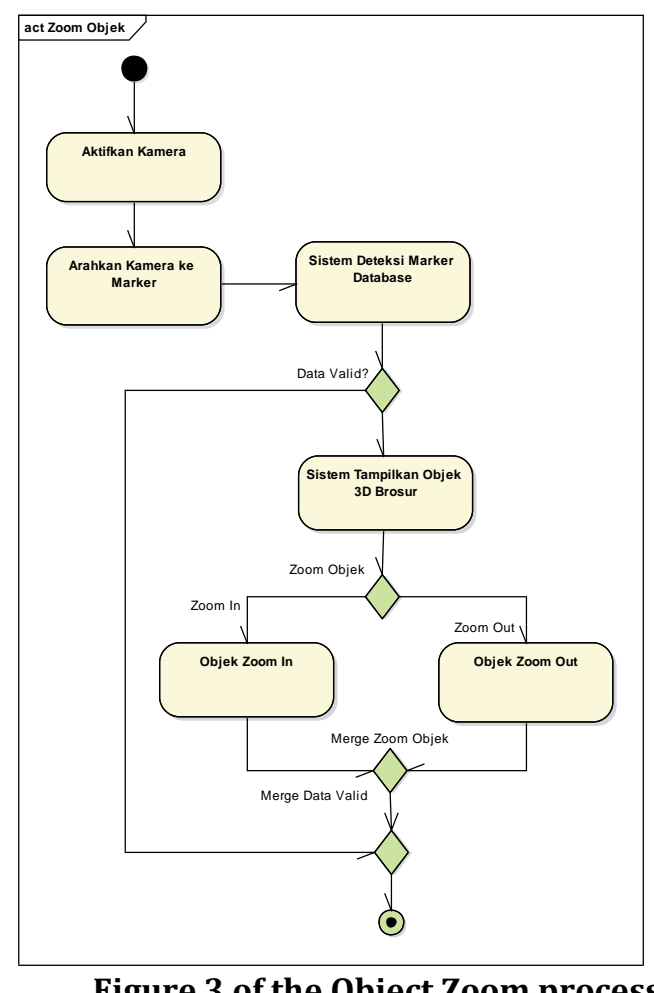

In Figure 3 above illustrates the activity diagram of the user (user) to display Zoom In or Zoom Out with augmented reality technology.

\section{Application Flow Chart}

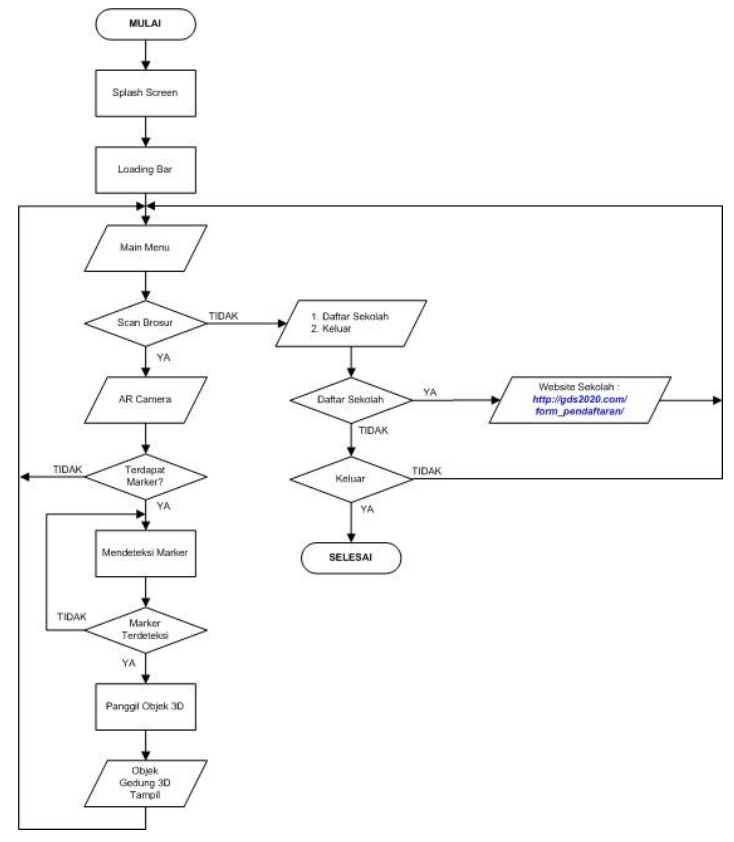

Figure 4 Application Flow Diagram 
In Figure 4 above we can find out the order of the course of the interactive brochure application.

\section{State Transition Diagram}

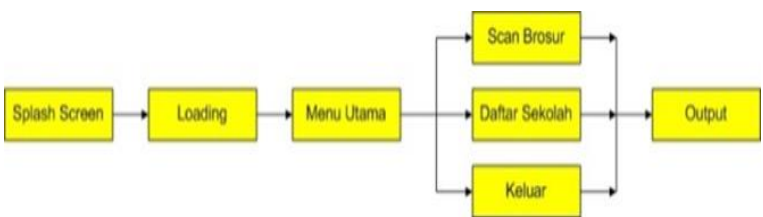

Figure 5. State Transition Main Menu Diagram

From Figure 5 above, it can be seen that the design of the software designed in this paper is related to an interactive brochure application with augmented reality technology.

\section{Application Navigation Structure}

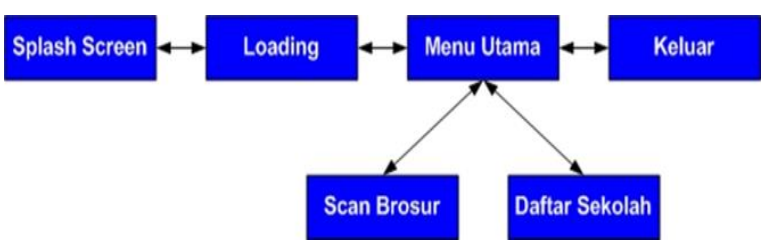

Figure 6. Mixed Navigation Structure

In Figure 6 above, it can be seen from each of the elements in the Android-based interactive brochure application that have links to one another.

\section{Graphical User Interface Design}

\section{a. Splash Screen Display}

It is a graphical control element consisting of a window containing an image, logo, and software version. A splash screen usually appears the first time the application is run. As in figure 7 below.

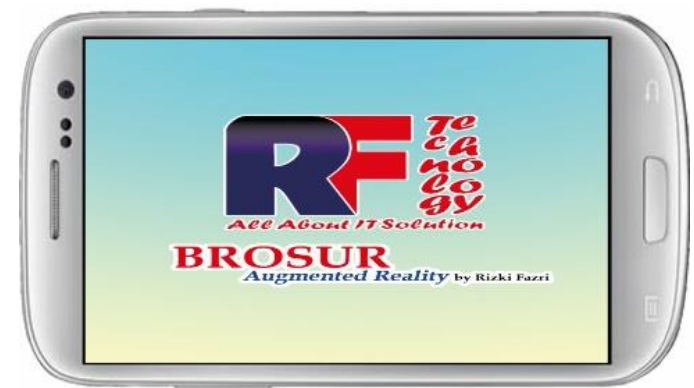

Figure 7. Splash Screen Interactive Brochure

The Splash screen created is the initial display of the application created which estimates interactive brochures using augmented reality technology.

\section{b. Main Display Menu}

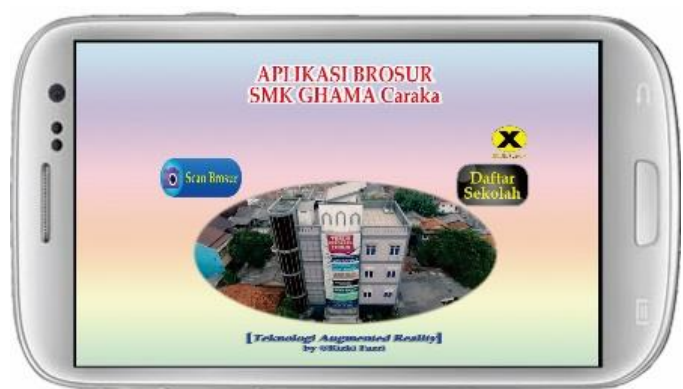

Figure 8. Main Menu Interactive Brochure

In Figure 8 above the main menu, users can scan brochures that can display three-dimensional images of buildings, users can also click the school list button and the application exit button.

\section{c. AR Camera Display}

In the Augmented Reality display on the user's smartphone, the Android will ask permission to access the user when the application is first installed on the smartphone, as shown in Figure 9 below.

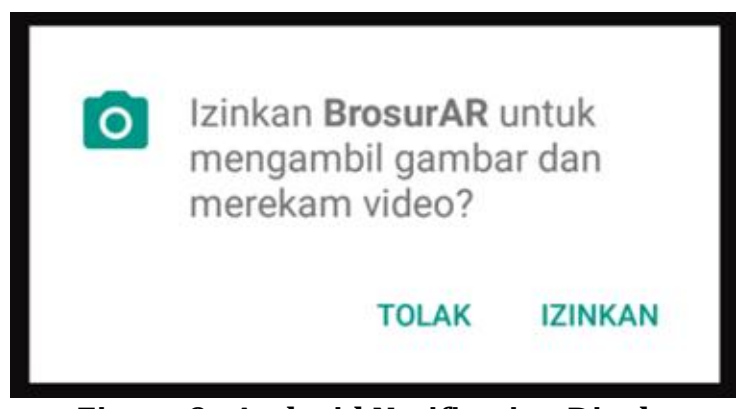

Figure 9. Android Notification Display

After the user chooses to allow, the application will automatically activate the camera to capture the Marker that has been created and a threedimensional object will appear virtually above the brochure that has been created.

\section{d. Augmented Reality Display}

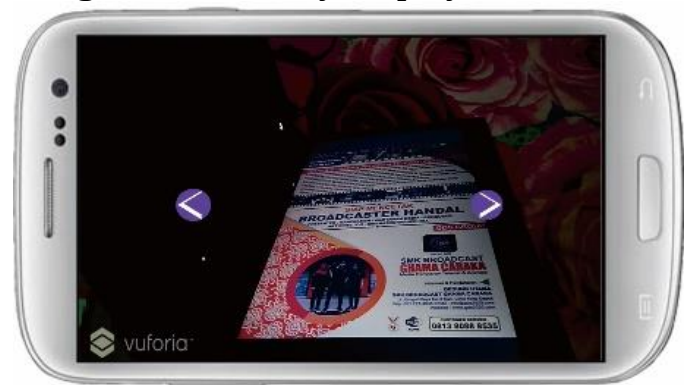

Figure 10. AR Camera Display 
In Figure 10 above you can see the camera scan process by the user in the existing brochure.

e. Marker display detected

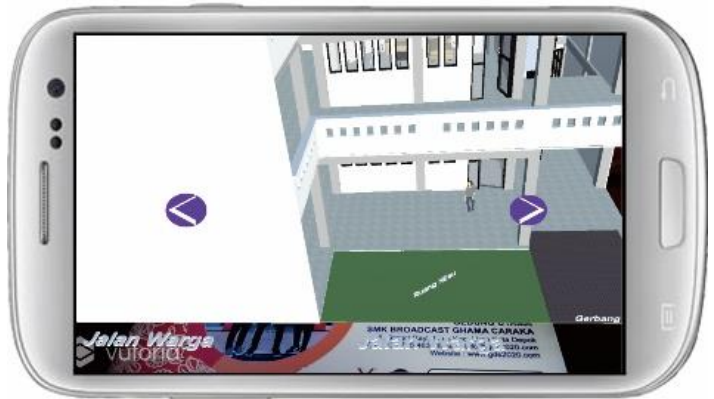

Figure 11. Marker display detected

In Figure 11 above when the marker display is detected, then the three-dimensional object that has been previously designed will call a virtual object that will appear above the brochure.

\section{f. Registration Display Form}

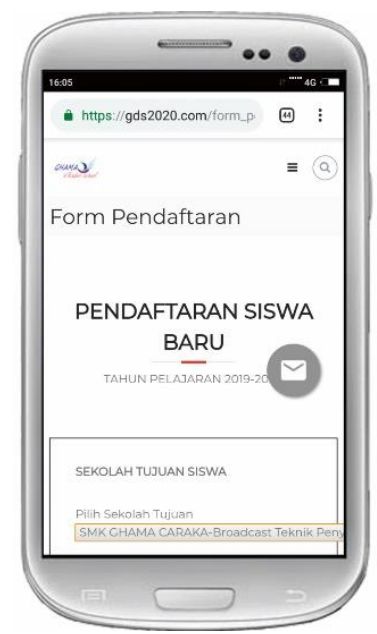

Figure 12. Display Registration Form

In the application that has been made, when the user selects the school register button, the application automatically redirects to the new student registration page.

\section{Construction}

In software testing applications we can do in several ways namely, functionality testing, compatibility testing, usability testing, and performance testing. At this writing, the author tries to measure compatibility testing. Where compatibility testing is done by using installation on the device and running the application on the device. Here there are 40 devices available. The results of the test can be seen in the following table:

Table 5. Compatibility Test Results

\begin{tabular}{clccc}
\hline No & \multicolumn{1}{c}{ Testing } & Walk & Failed & Score \\
\hline 1 & $\begin{array}{l}\text { Installation } \\
\text { on an Android } \\
\text { device }\end{array}$ & 40 & 0 & 40 \\
\hline $\begin{array}{l}\text { Approve the } \\
\text { application on } \\
\text { Android } \\
\text { devices }\end{array}$ & 40 & 0 & 40 \\
\hline$\quad$ Total & 80 & 0 & 80 \\
\hline & Percentage & $80 / 80 \times 100 \%=100 \%$ \\
\hline
\end{tabular}

From the results of compatibility testing in the table above, it produces a $100 \%$ percent when the device is installed and does not cause an error. You could say the brochure application with AR technology meets the aspect of compatibility.

Table 6. Testing of Mobile Devices

\begin{tabular}{|c|c|c|c|}
\hline No & Mobile type & Mobile Specifications & Information \\
\hline \multirow{4}{*}{1} & \multirow{4}{*}{$\begin{array}{l}\text { Acer Liquid } \\
23\end{array}$} & RAM 512 MB & \multirow{4}{*}{$\begin{array}{l}\text { Application Not } \\
\text { Installed }\end{array}$} \\
\hline & & Camera $3 \mathrm{MP}$ & \\
\hline & & Android 4,2 & \\
\hline & & $\begin{array}{l}\text { GHz Dual Core } 1 \\
\text { processor }\end{array}$ & \\
\hline \multirow{5}{*}{2} & \multirow{5}{*}{ Nexus 7} & RAM 1 GB & \multirow{5}{*}{$\begin{array}{l}\text { Application Is } \\
\text { Installed and } \\
\text { Running with } \\
\text { Clear 3D Object } \\
\text { Results }\end{array}$} \\
\hline & & Camera 5 MP & \\
\hline & & Android 4,2 Jelly Bean & \\
\hline & & 1.3 GHz Quad-Core & \\
\hline & & Processor & \\
\hline \multirow{4}{*}{3} & \multirow{4}{*}{$\begin{array}{l}\text { Samsung } \\
\text { Galaxy } \\
\text { Grand } \\
\text { Prime }\end{array}$} & RAM 1 GB & \multirow{4}{*}{$\begin{array}{l}\text { Application Is } \\
\text { Installed and } \\
\text { Running with } \\
\text { Clear 3D Object } \\
\text { Results }\end{array}$} \\
\hline & & Camera 5 MP & \\
\hline & & Android 4,4 Kitkat & \\
\hline & & 1,2 GHz Quad-Core & \\
\hline \multirow{4}{*}{4} & \multirow{4}{*}{$\begin{array}{l}\text { Oppo Find } \\
\text { Clover R815 }\end{array}$} & RAM 1 GB & \multirow{4}{*}{$\begin{array}{l}\text { Application Is } \\
\text { Installed and } \\
\text { Running with } \\
\text { Clear 3D Object } \\
\text { Results }\end{array}$} \\
\hline & & Camera $8 \mathrm{MP}$ & \\
\hline & & Android 4,4 Kitkat & \\
\hline & & $\begin{array}{l}1,3 \mathrm{GHz} \text { Quad-Core } \\
\text { processor }\end{array}$ & \\
\hline \multirow{4}{*}{5} & \multirow{4}{*}{$\begin{array}{l}\text { Smartfren } \\
\text { Andromax } \\
\text { C3 }\end{array}$} & RAM 512 MB & \multirow{4}{*}{$\begin{array}{l}\text { Application } \\
\text { Installed But } \\
\text { Not Running }\end{array}$} \\
\hline & & Camera 5 MP & \\
\hline & & Android 4,4 Kitkat & \\
\hline & & $\begin{array}{l}\text { 1,2 GHz Dual-Core } \\
\text { processor }\end{array}$ & \\
\hline \multirow{4}{*}{6} & \multirow{4}{*}{$\begin{array}{l}\text { Oppo Finds } \\
\text { Mini }\end{array}$} & RAM 1 GB & \multirow{4}{*}{$\begin{array}{l}\text { Application Is } \\
\text { Installed and } \\
\text { Running with } \\
\text { Clear 3D Object } \\
\text { Results }\end{array}$} \\
\hline & & Camera 8 MP & \\
\hline & & Android 4,4 Kitkat & \\
\hline & & $\begin{array}{l}\text { 1,3 GHz Quad-Core } \\
\text { processor }\end{array}$ & \\
\hline
\end{tabular}

Table 6 explains the specifications of an Android-based mobile phone that can be used for the AR Brochure application. And of the six cellphones used by researchers to implement the AR Brochure application, there are only 4 (four) that support, Nexus 7, Oppo Find Clover R815, Samsung Galaxy Grand Prime and Oppo Finds Mini. 
Table 7 Results of Device Application Testing

\begin{tabular}{|c|c|c|c|c|c|c|c|}
\hline \multirow{2}{*}{ No } & \multirow{2}{*}{ Component } & \multicolumn{6}{|c|}{ Testing Results } \\
\hline & & Device 1 & Device 2 & Device 3 & Device 4 & Device 5 & Device 6 \\
\hline 1 & $\begin{array}{l}\text { Opening the } \\
\text { Application }\end{array}$ & Functioning & Functioning & Functioning & Functioning & Functioning & Functioning \\
\hline 2 & $\begin{array}{l}\text { Look at the } \\
\text { Splash } \\
\text { Menu }\end{array}$ & Functioning & Functioning & Functioning & Functioning & Functioning & Functioning \\
\hline 3 & $\begin{array}{l}\text { Look at the } \\
\text { Main Menu }\end{array}$ & Functioning & Functioning & Functioning & Functioning & Functioning & Functioning \\
\hline 4 & $\begin{array}{l}\text { Open the } \\
\text { Help Menu }\end{array}$ & Functioning & Functioning & Functioning & Functioning & Functioning & Functioning \\
\hline 5 & $\begin{array}{l}\text { Open the } \\
\text { Variation } \\
\text { Menu }\end{array}$ & Functioning & Functioning & Functioning & Functioning & Functioning & Functioning \\
\hline 6 & $\begin{array}{l}\text { See Zoom } \\
\text { In / Zoom } \\
\text { Out }\end{array}$ & Functioning & Functioning & Functioning & Functioning & Functioning & Functioning \\
\hline 7 & $\begin{array}{l}\text { Open the } \\
\text { Exit Menu }\end{array}$ & Functioning & Functioning & Functioning & Functioning & Functioning & Functioning \\
\hline 8 & $\begin{array}{l}\text { Open the } \\
\text { AR Menu }\end{array}$ & Functioning & Functioning & $\begin{array}{c}\text { Not } \\
\text { functioning }\end{array}$ & Functioning & $\begin{array}{c}\text { Not } \\
\text { functioning }\end{array}$ & Functioning \\
\hline 9 & $\begin{array}{l}\text { 3D } \\
\text { Brochure } \\
\text { Object }\end{array}$ & Functioning & Functioning & $\begin{array}{c}\text { Not } \\
\text { functioning }\end{array}$ & Functioning & $\begin{array}{c}\text { Not } \\
\text { functioning }\end{array}$ & Functioning \\
\hline 10 & $\begin{array}{l}\text { Brochure } \\
\text { Animation }\end{array}$ & Functioning & Functioning & $\begin{array}{c}\text { Not } \\
\text { functioning }\end{array}$ & Functioning & $\begin{array}{c}\text { Not } \\
\text { functioning }\end{array}$ & Functioning \\
\hline 11 & Sound & Functioning & Functioning & $\begin{array}{c}\text { Not } \\
\text { functioning }\end{array}$ & Functioning & $\begin{array}{c}\text { Not } \\
\text { functioning }\end{array}$ & Functioning \\
\hline
\end{tabular}

Table 7 above relates to table 6 which discussed the specifications of mobile phones, so in table 7 , researchers explain the functions that can be used by several mobile phones in this AR Brochure application.

Table 8 Minimum Distance Testing Results

\begin{tabular}{ccccc}
\hline No & $\begin{array}{c}\text { Distance } \\
\text { (CM) }\end{array}$ & $\begin{array}{c}\text { Marker } \\
\mathbf{1 0} \mathbf{~ c m ~} \mathbf{~} \\
\mathbf{1 0} \mathbf{~ c m}\end{array}$ & $\begin{array}{c}\text { Marker } \\
\mathbf{1 3} \mathbf{~ c m ~} \mathbf{~ 1 3} \\
\mathbf{~ c m}\end{array}$ & $\begin{array}{c}\text { Marker } \\
\mathbf{1 8} \mathbf{~ c m ~} \mathbf{~} \\
\mathbf{1 8 ~} \mathbf{~ c m}\end{array}$ \\
\hline 1 & 100 & $\mathrm{X}$ & $\mathrm{X}$ & $\mathrm{X}$ \\
\hline 2 & 90 & $\mathrm{X}$ & $\mathrm{X}$ & $\mathrm{X}$ \\
\hline 3 & 80 & $\mathrm{X}$ & $\mathrm{X}$ & $\mathrm{X}$ \\
\hline 4 & 70 & $\mathrm{X}$ & $\mathrm{X}$ & $\mathrm{V}$ \\
\hline 5 & 60 & $\mathrm{X}$ & $\mathrm{V}$ & $\mathrm{V}$ \\
\hline 6 & 50 & $\mathrm{~V}$ & $\mathrm{~V}$ & $\mathrm{~V}$ \\
\hline 7 & 40 & $\mathrm{~V}$ & $\mathrm{~V}$ & $\mathrm{~V}$ \\
\hline 8 & 30 & $\mathrm{~V}$ & $\mathrm{~V}$ & $\mathrm{X}$ \\
\hline 9 & 20 & $\mathrm{~V}$ & $\mathrm{~V}$ & $\mathrm{X}$ \\
\hline 10 & 10 & $\mathrm{~V}$ & $\mathrm{X}$ & $\mathrm{X}$ \\
\hline \multicolumn{5}{c}{ In addition to testing devices and testing }
\end{tabular}
mobile devices, the AR Brochure application this is also very necessary for testing the Minimum
Distance between the camera and the Marker (Object).

Table 9 Test Results of Mobile Device Angles to Markers

\begin{tabular}{ccccc}
\hline & & \multicolumn{3}{c}{ Marker } \\
\cline { 3 - 5 } No & $\begin{array}{c}\text { Distance } \\
\text { (CM) }\end{array}$ & $\begin{array}{c}\text { Marker } \\
\mathbf{1 0} \mathbf{~ c m ~} \mathbf{x} \\
\mathbf{1 0 ~} \mathbf{~ m}\end{array}$ & $\begin{array}{c}\text { Marker } \\
\mathbf{1 3} \mathbf{~ c m ~} \mathbf{~} \\
\mathbf{1 3} \mathbf{~ c m}\end{array}$ & $\begin{array}{c}\text { Marker } \\
\mathbf{1 8} \mathbf{~ c m ~} \mathbf{~ 1 8} \\
\mathbf{~ c m}\end{array}$ \\
\hline 1 & 100 & $\mathrm{~V}$ & $\mathrm{~V}$ & $\mathrm{~V}$ \\
\hline 2 & 90 & $\mathrm{~V}$ & $\mathrm{~V}$ & $\mathrm{~V}$ \\
\hline 3 & 80 & $\mathrm{~V}$ & $\mathrm{~V}$ & $\mathrm{~V}$ \\
\hline 4 & 70 & $\mathrm{~V}$ & $\mathrm{~V}$ & $\mathrm{~V}$ \\
\hline 5 & 60 & $\mathrm{X}$ & $\mathrm{X}$ & $\mathrm{V}$ \\
\hline 6 & 50 & $\mathrm{X}$ & $\mathrm{X}$ & $\mathrm{X}$ \\
\hline 7 & 40 & $\mathrm{X}$ & $\mathrm{X}$ & $\mathrm{X}$ \\
\hline 8 & 30 & $\mathrm{X}$ & $\mathrm{X}$ & $\mathrm{X}$ \\
\hline 9 & 20 & $\mathrm{X}$ & $\mathrm{X}$ & $\mathrm{X}$ \\
\hline 10 & 10 & $\mathrm{X}$ & $\mathrm{X}$ & $\mathrm{X}$ \\
\hline & & & & \\
\hline
\end{tabular}

Table 9 above the test results compared with table 8 , the greater the distance used, and the greater the marker, the more visible the object is. 
Table 10. Brochure Voter Questionnaire Results AR

\begin{tabular}{|c|c|c|c|c|c|c|}
\hline \multirow{2}{*}{ No } & \multirow{2}{*}{ Software Engineering Aspects } & \multicolumn{5}{|c|}{ Response } \\
\hline & & 1 & 2 & 3 & 4 & 5 \\
\hline \multicolumn{7}{|c|}{ Software Engineering Aspects } \\
\hline 1 & Ease of Running the Application & 0 & 0 & 6 & 59 & 35 \\
\hline 2 & Disadvantages of Running an Application & 0 & 0 & 7 & 62 & 31 \\
\hline 3 & Ease of Access Application Features & 0 & 0 & 9 & 60 & 31 \\
\hline 4 & Accuracy in Object Position & 0 & 0 & 16 & 53 & 31 \\
\hline 5 & Complete Application Features & 0 & 0 & 21 & 73 & 6 \\
\hline Total & & $\mathbf{0}$ & $\mathbf{0}$ & 59 & 307 & 134 \\
\hline \multicolumn{7}{|c|}{ Functionality Aspects } \\
\hline 6 & Process Performance See Object Details & 0 & 0 & 7 & 70 & 23 \\
\hline 7 & Navigation Process Performance & 0 & 0 & 17 & 55 & 28 \\
\hline 8 & Process Performance Place Objects & 0 & 0 & 12 & 60 & 28 \\
\hline 9 & Open Process Website Performance & 0 & 0 & 13 & 59 & 28 \\
\hline 10 & The ease that AR provides in recognizing objects & 0 & 0 & 11 & 44 & 45 \\
\hline Total & & 0 & 0 & 60 & 288 & 152 \\
\hline \multicolumn{7}{|c|}{ Virtual Communication Aspects } \\
\hline 11 & Application Interface & 0 & 0 & 27 & 51 & 22 \\
\hline 12 & Laying Information & 0 & 0 & 15 & 63 & 22 \\
\hline 13 & The type and size of the letters used are readable & 0 & 0 & 6 & 58 & 36 \\
\hline 14 & AR brochure combination on application & 0 & 0 & 13 & 60 & 27 \\
\hline 15 & Smoothness Brochure AR & 0 & 0 & 10 & 55 & 35 \\
\hline Total & & 0 & 0 & 71 & 287 & 142 \\
\hline
\end{tabular}

Information :

$\begin{array}{ll}\text { 5: Very Good } & \text { - 3: Enough - 1: Not Good } \\ \text { 4: Good } & \text { - 2: Not so good }\end{array}$

This questionnaire was distributed by 100 respondents who were connected with AR Brochure users in the search for information about existing facilities and infrastructure at SMK Ghama Caraka Depok.

\section{Deployment Diagram}

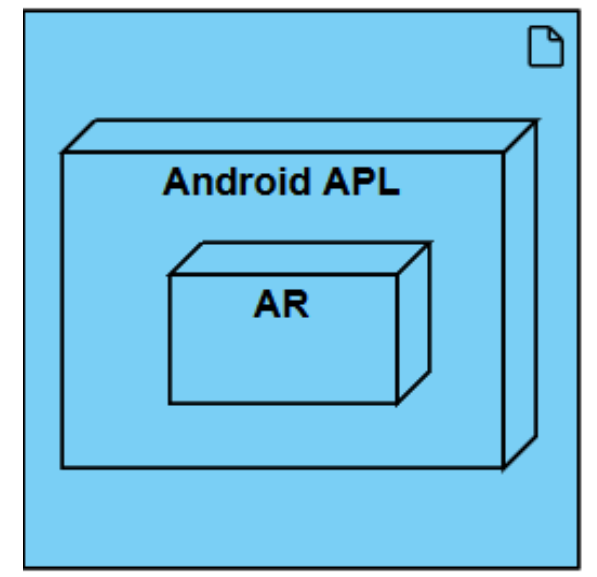

Gambar 13. Deployment Diagram

In Figure 13 above illustrates the architecture used on the system designed. To support the application, hardware and software are needed. There are 2 (two) hardware devices used by researchers in developing this application including Mobile (Hp), researchers use Xiaomi Redmi4 Mobile to run applications, with CPU (Quad-Core Max 1.4GHz), 2GB RAM, Android version 6.0.1 (Marshmallow) and Computers for all phases of application work with CPU (Intel Core-i5 2GHz), 2GB RAM, 500GB HDD. For Smartphone Specifications, at a minimum have the following specifications:

Table 11 Smartphone Hardware Specifications

\begin{tabular}{ll}
\hline Specification & \multicolumn{1}{c}{ Remarks } \\
Chipset & $\begin{array}{l}\text { Qualcomm MSM8917 Snapdragon } \\
425\end{array}$ \\
\hline CPU & Quad-core 1.4 GHz Cortex-A53 \\
\hline GPU & Adreno 308 \\
\hline $\begin{array}{l}\text { Versi } \\
\text { Android }\end{array}$ & 6.0 .1 (Marshmallow) \\
\hline RAM & $2 \mathrm{~GB}$ \\
\hline
\end{tabular}

\section{Code Making Program}

The C\# programming language and the tools used already have a Graphical User Interface (GUI) that provides user usage programming in making this system is included in object-based programming. 


\section{CONCLUSIONS AND SUGGESTIONS}

\section{Conclusion}

The need for innovation in marketing each product by changing conventional brochures into augmented reality technology brochures. The design of virtual objects becomes a very high value by using a three-dimensional (3D) display and allows not only static but can also be displayed in motion. The ease of use of this application makes prospective registrants interested and understand using it so that it is easier to use (User Friendly). The AR Brochure application can run well on devices with minimum RAM specifications (1.5 GB). This application can test the input and output from the AR menu, the AR input menu is a 3D Brochure marker, while the AR menu output is an animated 3D object and sound. The aspects used in the questionnaire consisted of 3 namely Software Engineering Aspects with user selection at point 4 (four) with a total of 307 out of 5 items, User selection functionality aspects at point 4 (four) with a total of 288 out of a total of 5 items and Aspects Communication The selection of virtual users is in point 4 (four) with a total of 287 out of 5 items.

\section{Suggestion}

It is recommended that SMK GHAMA Caraka can use this application to get more prospective students or prospective applicants every year. Virtual objects that are displayed can be changed according to their individual needs.

\section{REFERENCE}

Abdullah, D., Sani, A., \& Hasan, A. (2019). Pemanfaatan Teknologi Augmented Reality Pada Media Pengenalan Bangunan Bersejarah Rumah Kediaman Bung Karno Bengkulu Berbasis Android. Pseudocode, 6(1), 21-29. https://doi.org/10.33369/pseudocode.6.1.2 $1-29$

Adami, F. Z., \& Budihartanti, C. (2016). Penerapan Teknologi Augmented Reality Pada Media Pembelajaran Sistem Pencernaan Berbasis Android. Teknik Komputer AMIK BSI, 2(1), 122-131.

Daniel Rembeth. (2020). Virtual Reality dan Augmented Reality Dapat Mendongkrak
Perekonomian Global Hingga 1,4triliun poundsterling Pada 2030. Https://Pressrelease.Kontan.Co.Id/.

Indarti, I. (2017). Aplikasi Pengenalan Pahlawan Nasional Di Pulau Jawa Untuk Siswa Sd Berbasis Android Studi Kasus Pada SDN Pondok Pinang 10 Pagi Jakarta Selatan. Jurnal Pilar Nusa Mandiri, 13(1), 145-150. https://doi.org/10.33480/PILAR.V13I1.159

Mustaqim, I., \& Kurniawan, N. (2017). Pengembangan Media Pembelajaran Pai Berbasis Augmented Reality. Jurnal Edukasi Elektro, 1(1), 36-39. https://doi.org/https://doi.org/10.21831/je e.v1i1.13267

Rizal, M., \& Rusmin, M. (2018). Pengembangan Aplikasi E-Catalog Augmented Reality Sebagai Media Pemasaran Property. Inspiration: Jurnal Teknologi Informasi Dan Komunikasi, $\quad$ 8(2), 129-134. https://doi.org/10.35585/inspir.v8i2.2473

Setiawan, S. I. A. (2011). Google SketchUp Perangkat Alternatif dalam Pemodelan 3D. Jurnal ULTIMATICS, 3(2), 6-10. https://doi.org/10.31937/ti.v3i2.298

Suryawinata, B. A. (2010). Pemanfaatan Augmented Reality Dalam Memvisualisasikan Produk Perumahan Melalui Internet. ComTech: Computer, Mathematics and Engineering Applications, 1(2),

758. https://doi.org/10.21512/comtech.v1i2.258 3

Yayasan Pendidikan GHAMA d'leader school. (2018). Company Profile Lembaga Pendidikan GHAMA. Yayasan Pendidikan GHAMA d'leader school.

Yuliati, T., Utami, E., \& Al Fatta, H. (2014). Perancangan Mobile Augmented Reality Dengan Metode Interactive Multimedia System Design Development (Studi Kasus: Brosur Di Sekolah Tinggi Teknologi Dumai). Data Manajemen Dan Teknologi Informasi (DASI), 15(1), 54-60. https://www.ojs.amikom.ac.id/index.php/da si/article/view/183/0 